\title{
CHANGES IN THE TRANSPORT CAPACITY OF POLISH INLAND WATERWAYS AGAINST THE BACKGROUND OF EUROPEAN WATERWAY USE FOR TRANSPORT
}

\begin{abstract}
Lower environmental impact of inland waterway transport causes its development to be high on the agenda of the sustainable transport policy. In the above context, the purpose of this article is to discuss the transport function of Polish inland waterways against the background of how primary European inland waterway systems are used. The desk research method was used to analyse waterway use, involving review and consolidation of statistics from various sources capturing freight transport on the primary inland waterways in Europe. Research has shown that inland waterways in Western Europe, regardless of the decline in freight transport in 2009, continue to be important for transport, and their performance may even be higher than that of the infrastructure used for other modes of transport. The transport function of inland waterways in Poland is fading as a consequence of the failure to perform multipurpose waterway management. The above is inconsistent with sustainable transport development priorities adopted by the EU.
\end{abstract}

Keywords: inland waterway transport, inland waterways, freight transport JEL: R40

\section{Introduction}

Inland waterway transport is a vital link of the transport chain in Western Europe. Following a decline in freight transport in 2009, by 2017 inland waterway freight volume grew by $2.7 \%$ on average per year, coming to 558.3 million tonnes in EU-28 countries (Eurostat, 2019). It can be expected that inland waterway transport will consolidate its position in the transport system of Western Europe, 
in particular in the Rhine basin countries, where investment activities are initiated to reinforce the transport function of waterways.

In countries where inland waterways are managed in conformity with multipurpose water management requirements, inland waterway transport activity outperforms road or rail transport.

The development of inland waterways in Poland does not follow the European trend. This mode of transport has been neglected in terms of both investments and maintenance projects. The ever-continuing degradation waterways means that regardless of a relatively stable overall transport volume (domestic and international transport), domestic inland waterway transport has been clearly dwindling. The purpose of this paper is to discuss the transport function of inland waterways in Poland against the background of how the primary inland waterway systems in Europe are used, and to demonstrate that if the current trends in Poland persist, Polish inland waterway transport may cease to exist, with all its ramifications for the economy (in particular for sea ports).

\section{Methodology and theory}

Desk research method was used to analyse how inland waterways are used in Europe and Poland, which involved the analysis, review and consolidation of the existing statistics from various sources, such as: analytical reports, Internet, press. The accumulated statistical material from various sources was then arranged and presented as statistical series and charts, and subsequently analysed with basic descriptive statistical tools.

Proper use of inland waterways for transport is consistent with the sustainable development strategy. It currently represents one of the primary paradigms for growth (Załoga, 2013). The extent of inland waterway use for transport may also indicate the level at which multipurpose development of such waterways stands. It can be argued that incapacity to deliver the transport function means that inland waterway investment projects are one-off undertakings and thus do not fulfil the requirements of multipurpose management (Wojewódzka-Król, Rolbiecki, 2017).

\section{Results}

The most important conclusions include:

- inland waterways in Europe do not lose their importance for transport, despite a decline in freight transport in 2009;

- in many European countries, performance of inland waterways is higher than the performance of other transport modes;

- freight transport performance of Polish inland waterways is incomparably lower than for rail and road transport, and significantly lower than for inland waterways in other European countries; 
- Transport function of Polish inland waterways is on the wane and, in effect, the projections for domestic inland waterway transport proved to be too optimistic.

\section{Use of inland waterways for transport in Europe}

The primary area of inland waterway transport activity in Europe is the Rhine waterway. The total volume of freight transported on the Rhine has been invariably over 300 million tonnes per year and accounts for $2 / 3$ of freight transported on European inland waterways. Freight transport volume in the Rhine delta, from the German-Dutch border to its estuary at the North Sea, is estimated to significantly exceed 100 million tonnes. These are only estimates because freight on this waterway is registered in the official statistics of the Central Commission for the Navigation of the Rhine only for the section from Basel (Switzerland) to the German-Dutch border, and referred to as Traditional Rhine. Figure 1 shows that, prior to 2009, freight volume on the Traditional Rhine exceeded 200 million tonnes, followed by a decline, currently reaching a stable level of ca. 190 million tonnes.

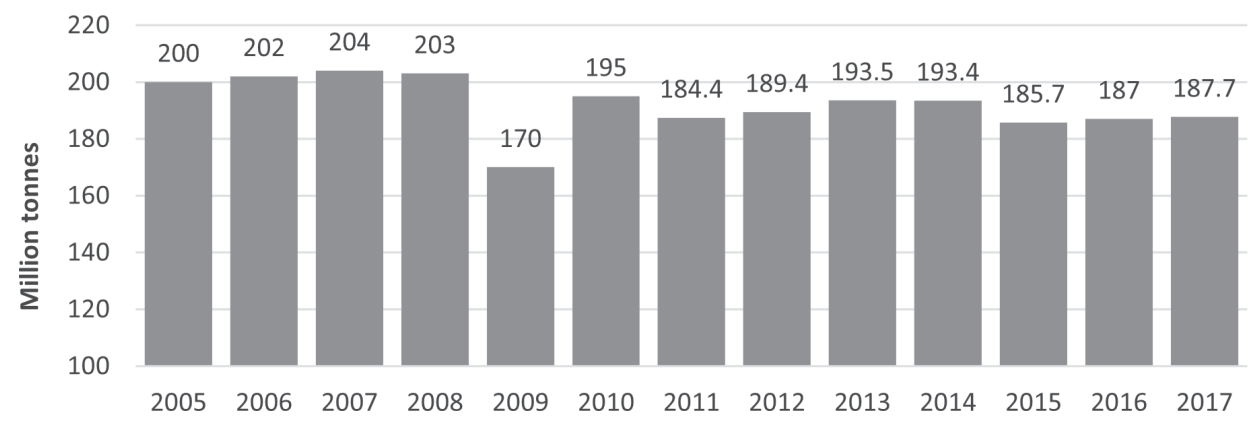

Figure 1. Traditional Rhine (Basel - German-Dutch border) in million tonnes (to 2010, estimates)

Source: (own elaboration; Zentralkommission für die Rheinschifffahrt 2018; Bundesverband der Deutschen Binnenschifffahrt e.V. (BDB) 2018a)

Next to the Rhine axis, the second most important transport direction is the northsouth axis, with its natural and artificial inland waterways of the Netherlands, Belgium and northern France. International inland waterway freight transport between those countries is estimated to reach ca. 100 million tonnes annually, 80 million tonnes of which is transported between Belgium and the Netherlands. Waterways of the north-south axis are among those boasting the highest performance in Europe. While transport performance on the Traditional Rhine amounted to 40 billion $\mathrm{tkm}$ in 2017, it amounted to as much as 60 billion $\mathrm{tkm}$ for the north-south axis waterways (Zentralkommission für die Rheinschifffahrt, 2016; 2018).

Another primary inland waterway system in Europe is the east-west axis. The primary link of that axis is the Mittelland Canal, so important because it integrates the basins of: the Rhine, the Ems, the Weser, the Elbe, and also the Oder. 
This river canal sees the highest transport activity of all river canals in Germany (freight volume on this waterway accounts for nearly $50 \%$ of the freight volume of all canals) (Bundesverband der Deutschen Binnenschifffahrt, 2018a). Figure 2 shows that between 2005 and 2017 freight volume transported on the canal ranged between 23 and 20 million tonnes. The volume is therefore stable.

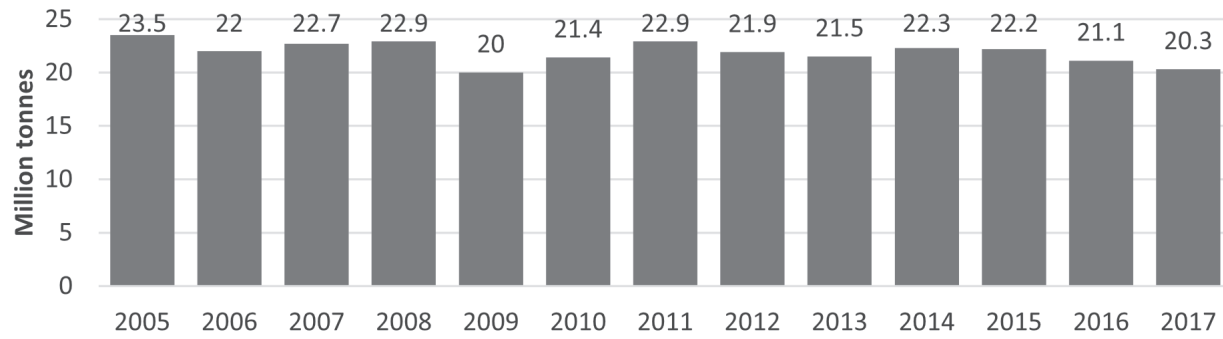

Figure 2. Freight volume transported on the Mittelland Canal in million tonnes

Source: (own elaboration; Zentralkommission für die Rheinschifffahrt 2016; Bundesverband der Deutschen Binnenschifffahrt e.V. (BDB) 2018a)

Next to an extensive network of canals, another important link of the east-west axis inland waterways, comprises rivers such as: the Elbe and the Weser, connecting Germany's industrial centres with sea ports of Hamburg and Bremerhaven. Regarding the Elbe, freight is transported primarily on its German section, and its volume is stable as shown in Figure 3. After a minor drop after 2009, to ca. 16 million tonnes, the freight volume on this waterway has recovered to ca. 18 million tonnes per year.

Elbe waterway

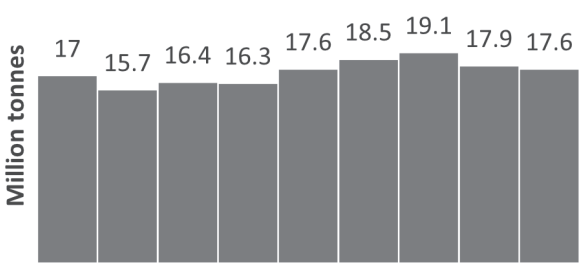

200920102011201220132014201520162017
Weser waterway

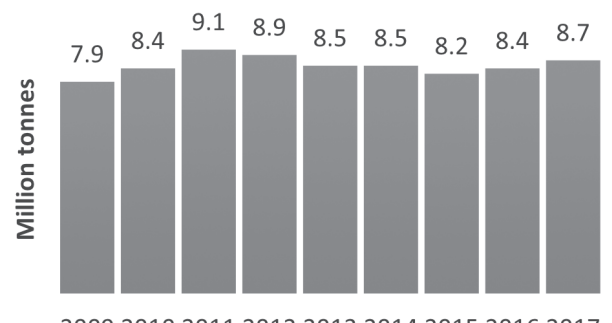

Figure 3. Freight transport volume on the Elbe and the Weser waterway in million tonnes Source: (own elaboration, Bundesverband der Deutschen Binnenschifffahrt e.V. (BDB) 2018a)

Freight volume shipped on the Weser (Figure 3) currently totals ca. 9 million tonnes (higher than in 2009) and most of it, similarly to the Elbe, is used for transport regarding the hinterland of the port of Bremerhaven, located at the end of this waterway.

Yet another important European waterway system is the south-east axis, i.e. Danube waterway with the Main-Danube canal. The Danube is very diverse in terms of hydroengineering features. Therefore, the Danube waterway is seen 
as having untapped transport potential. It is estimated that the share of the Danube in the total freight transport on European inland waterways was less than 10\% in 2017 (Donaukommission, 2018a). However, the volume is stable, as shown in Figure 4, at ca. 60 million tonnes per year, except for 2009, wih a decline to 44.6 million tonnes.

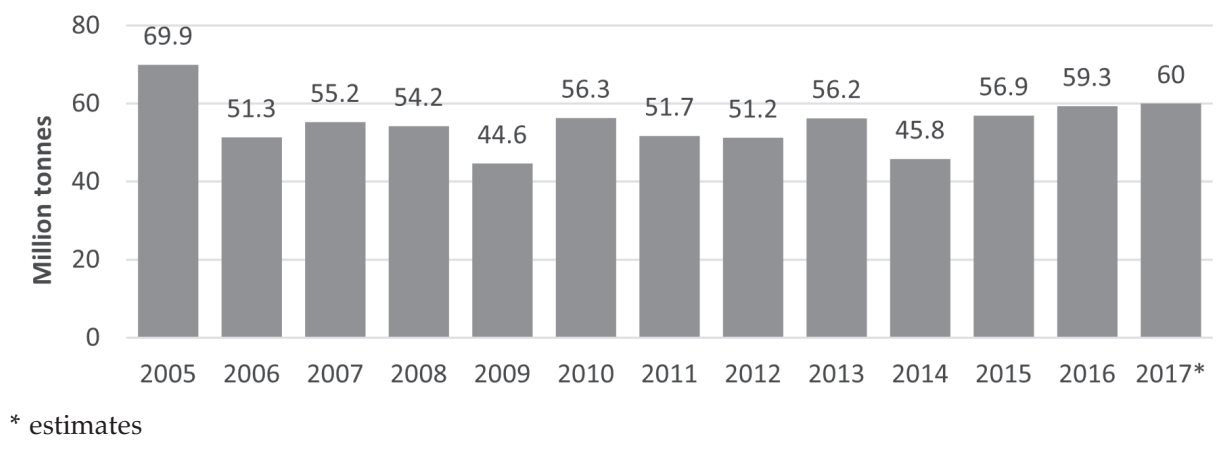

Figure 4. Danube waterway freight transport in million tonnes Source: (own elaboration; Dunaukommission 2017, 2018b)

It follows from the presented analysis that European inland waterways continue to play a vital transport role despite a certain decline in freight transport in 2009. Periodical fluctuations of the freight volume follow the economic cycle and may also be caused by different hydrological conditions in certain years. For example, 2018 saw a smaller freight volume on many waterways than in prior years. An exceptionally sever draught that started in June 2018 required the closing of many waterway sections, even on the Rhine (in southern Germany). In sections where navigation was possible, freight was transported only by low-tonnage vessels, and only at limited draught (Bundesverband der Deutschen Binnenschifffahrt, 2018b).

The identified inland waterway freight volume may be used to assess the performance of those waterways. Inland waterway transport infrastructure is used most in the Rhine basin countries. Considering both domestic and international transport, on average in 2017, there were 29 thousand tonnes per $1 \mathrm{~km}$ of an inland waterway in Germany, 58.5 thousand tonnes in the Netherlands, 13.4 thousand tonnes in France, and as much as 132 thousand tonnes in Belgium (Table 1). It was, respectively 3.3, 4.3, 4.2 and 8.6 times more than the freight volume per $1 \mathrm{~km}$ of active railway lines in those countries. Table shows that in the analysed countries the performance of inland waterways is also significantly higher than that of road transport infrastructure. 
Table 1. Performance of freight transport infrastructure in 2017 (thousand tonnes per $1 \mathrm{~km}$ of carriage)

\begin{tabular}{|l|c|c|c|c|c|c|}
\hline \multirow{2}{*}{ Country } & \multicolumn{3}{|c|}{$\begin{array}{c}\text { Load regarding domestic } \\
\text { and international road transport }\end{array}$} & \multicolumn{2}{c|}{ Load regarding domestic road transport } \\
\cline { 2 - 7 } & $\begin{array}{c}\text { Inland } \\
\text { waterways }\end{array}$ & Railways & Roads & $\begin{array}{c}\text { Inland } \\
\text { waterways }\end{array}$ & Railways & Roads \\
\hline Belgium & 132.7 & 15.5 & 1.9 & 33.2 & 4.6 & 1.5 \\
\hline Bulgaria & 34.6 & 4.0 & 7.5 & 2.3 & 1.8 & 5.9 \\
\hline Romania & 16.3 & 5.2 & 2.6 & 8.2 & 4.1 & 2.0 \\
\hline Germany & 29.0 & 8.9 & 13.7 & 7.2 & 5.8 & 13.2 \\
\hline France & 13.4 & 3.2 & 1.6 & 6.1 & 2.0 & 1.5 \\
\hline Netherlands & 58.5 & 13.5 & 4.8 & 18.1 & 0.9 & 3.8 \\
\hline Austria & 27.4 & 21.9 & 2.8 & 1.1 & 6.1 & 2.6 \\
\hline
\end{tabular}

Source: (own elaboration; Eurostat, 2019; European Commission, 2019)

High performance of inland waterways for transport purposes is also characteristic for the Danube basin countries, such as Romania, Bulgaria and Austria. In Romania for example, there were 16.3 thousand tonnes on average per $1 \mathrm{~km}$ of a waterway in 2017, and only 5.2 thousand tonnes per $1 \mathrm{~km}$ of a railway, and 2.6 thousand tonnes per $1 \mathrm{~km}$ of a road.

Inland waterways see more activity than other transport modes when it comes to domestic transport, however by a smaller margin. The above largely results from the peculiar characteristics of that mode of transport, namely that it operates to a greater extend on the international freight market compared to other modes of land transport. On average in 2008-2017, international inland waterway shipping in EU-28 accounted for 51\% of the entire freight transport, and for 52\% in EU-15 (Eurostat, 2019; GUS, 2018a).

Considering the existing trends, it may be expected that the importance of using European inland waterways for transport will not diminish in the longer perspective.

\section{Transport performance of Polish inland waterways}

The potential of the primary Polish inland waterways cannot match that of the Rhine waterway, but is still comparable to many other European waterways used for transport (e.g. the Elbe). There are many arguments in favour of using Polish inland waterways for transport:

- the primary waterways (the Oder, the Vistula) connect quickly growing sea ports with the hinterland;

- other modes of transport cannot fulfil growing shipping needs of the hinterland;

- Polish inland waterways are connected with the network of European waterways, which creates the development conditions for international shipping; 
- significant water requirement from other economic areas, flood hazards and energy generation potential of the lower Vistula and attractive riverside areas as tourism assets are arguments in favour of multipurpose waterway management, which will not only improve navigation conditions, but may also prove very profitable for the economy.

Disappointingly, low level of funding for the development and maintenance of inland waterways, as compared to other modes of transport, not only prevented the waterways from achieving the required technical class, but also caused them to seriously deteriorate. The requirements for international waterways in Poland, i.e. waterways of class IV and higher were met in 2017 only by 5.9\% of the waterways, that is by $214 \mathrm{~km}$ out of $3654 \mathrm{~km}$ of navigable inland waterways. The share has remained the same in Poland since 2007 (GUS, 2018a).

The condition of the waterway directly decides on its throughput capacity and in effect on its significance for transport. The problem of minor use for transport applies even to the Oder, considered the best waterway in Poland. Technical parameters of this waterway at $50.7 \%$ of its length do not even meet the requirements for class III. Out of the total of 47, this waterway has only 2 navigable weirs which comply with the technical conditions for at least class IV. Limited clearances under bridges are another source of serious problems. As many as 60 bridges on the Oder waterway do not meet the requirements for class IV, including 39 road and 18 railway bridges (Pieron, 2017).

In 2017, freight volume transported on the Oder Waterway (the Oder and the Gliwice Canal) totalled 2.1 million tonnes (Figure 5), a smaller number than in 2016, even though navigation on the Gliwice Canal resumed in July 2017 after 5 years (Gazeta.pl next 2017).

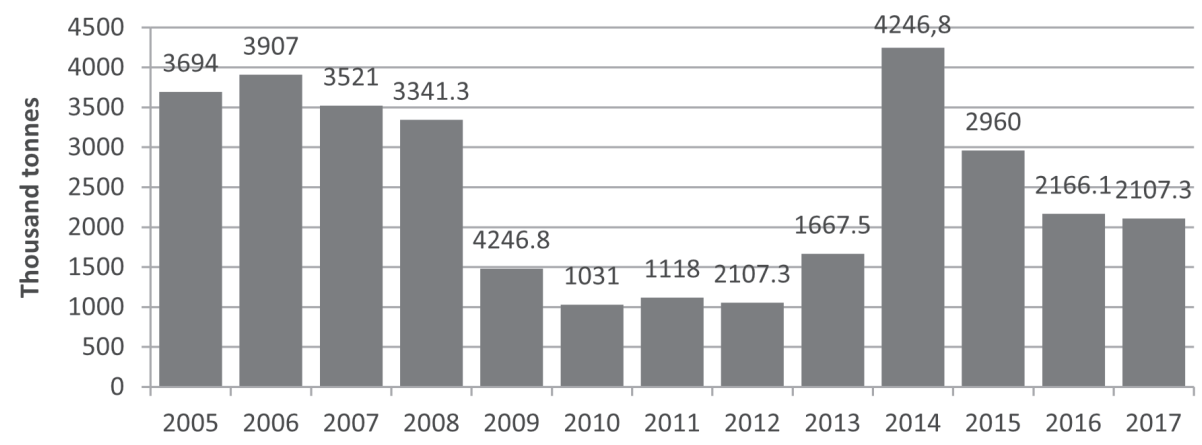

Figure 5. Oder waterway freight volume

Source: (own elaboration; GUS 2018b)

Even bigger navigation hindrances exist on the Vistula. As much as $80 \%$ of the waterway's length has parameters of class I and II only, which is too low for contemporary navigation requirements to ensure profitable freight shipping. It follows from Figure 6 that in 2017 freight shipping on the lower Vistula (one of the largest Polish inland ship owners - Żegluga Bydgoska sp. z o.o., operates at this section) totalled ca. 412 thousand tonnes. 


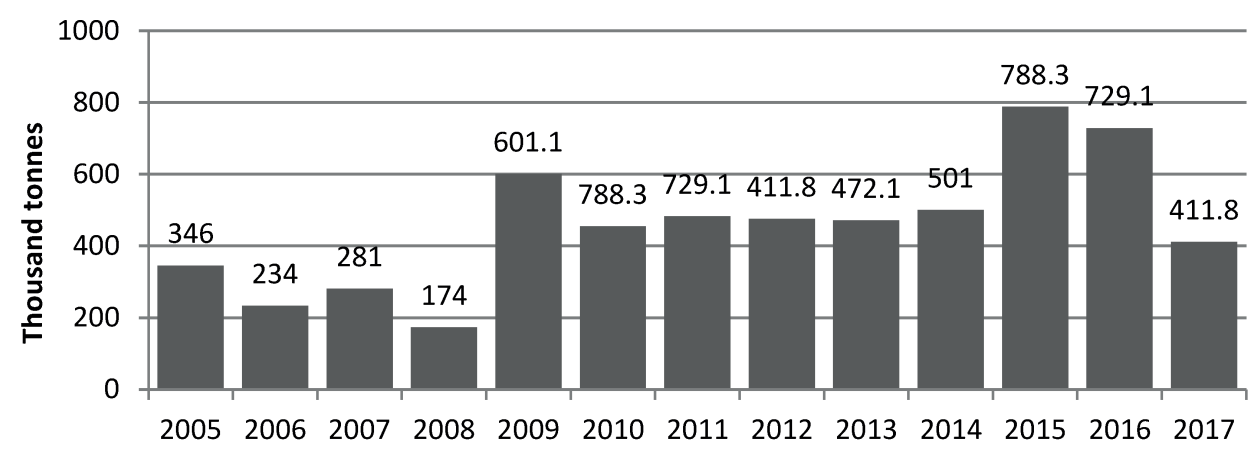

Figure 6. Lower Vistula waterway freight transport in 2010-2017 Source: (own elaboration; GUS 2018b)

The upper Vistula is as insignificant for transport as the lower Vistula. Inland freight transport on the upper Vistula is limited to short-distance shipping of aggregate extracted from the river bed, primarily for the needs of Kraków Metropolitan Area. As shown in Figure 7, freight transport on this Vistula section amounts to a mere 8.2 thousand tonnes.

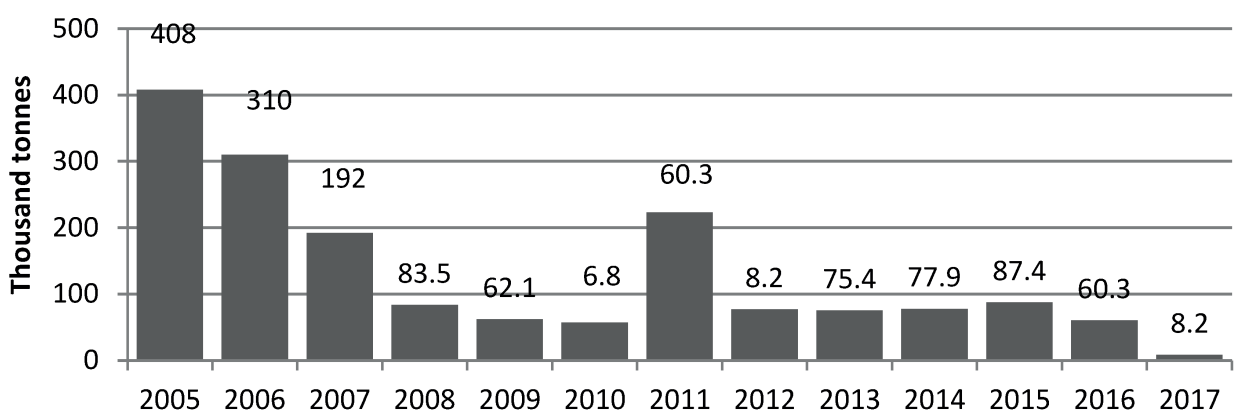

Figure 7. Upper Vistula waterway freight transport volume in 2010-2017 Source: (own elaboration; GUS 2018b)

Currently, permanent transport cannot be performed on the central Vistula (from the Sanna estuary to the Narew estuary). As this section is left unmaintained and grows wild, tourist or recreational navigation is also not present at this section.

Poor technical parameters of Polish waterways, their diversity, and their ever-more deteriorating condition make it difficult to arrange for long-distance transport. This in turn results in spatial shrinking of the services on the inland waterway transport market. Local transport takes place primarily on the lower and upper Vistula. Process-related transport (primarily regarding the aggregate extracted from the riverbed) takes place at this sections of the Vistula. In 2017, the average distance of such transport on the lower Vistula was $2.3 \mathrm{~km}$ and $8 \mathrm{~km}$ on the upper Vistula. Relative longer distances are observed for the Oder waterway. Still, they became significantly shorter in 2010-2017. In 2017, the average distance of domestic transport of 1 tonne was $34.3 \mathrm{~km}$, while in 2010 - $62 \mathrm{~km}$ (GUS, 2018b). 
Ongoing negligence in investment projects for inland waterways caused the domestic inland waterway transport projections to be too optimistic. Freight volume currently transported on Polish waterways is more than 2 times less than assumed in the projection of 2007 (Burnewicz, 2007a; 2007b; GUS, 2018a).

Under the circumstances, the freight transport performance of inland waterways is also insignificant. The assessment applies to domestic transport. The incorporation of international transport to measure Polish waterway transport performance would oversimplify the picture. International transport is primarily performed by Polish ship owners on the cabotage market (40\% of the total transport in 2017), and exports from Szczecin and through the Western Oder primarily take place on Western European waterways, accounting for $92.3 \%$ of total exported freight volume (GUS, 2018c). Considering the existing infrastructural constraints, there were merely 0.7 thousand tonnes of freight per $1 \mathrm{~km}$ of Polish inland waterways in 2017, while per $1 \mathrm{~km}$ of railroad it was 9.5 thousand tonnes, and per $1 \mathrm{~km}$ of a road -2.9 thousand tonnes transported on the domestic market (Eurostat, 2019).

\section{Conclusions}

The main conclusions of the study:

- considering the observed trends, it may be expected that the importance of the transport function of European inland waterways will not diminish in the longer perspective;

- a decline in the use of inland waterways for transport is inconsistent with the adopted EU priorities of sustainable transport development;

- limited capacity to deliver the transport function of inland waterways is a consequence of neglected multipurpose inland waterway development in Poland;

- the development of Polish inland waterway transport is a precondition for a sustained pace of growth of the sea ports and their position in Europe;

- higher freight volume on inland waterways depends on their multipurpose management and maintenance;

- the need to increase the significance of waterways for transport results from Poland's declaration to adapt inland waterways of international importance to the requirements of the AGN agreement, ratified on 6 March 2017.

\section{References}

Bundesverband der Deutschen Binnenschifffahrt e.V. (BDB) (2018a), Daten \& Fakten der Binnenschifffahrt, Duisburg. Available from https://www.binnenschiff.de/service/daten-fakten/.

Bundesverband der Deutschen Binnenschifffahrt e.V. (BDB) (2018b), Dürre in Deutschland erfordert das Handeln von Politik und Verwaltung - Binnenschiffahrt aufdem Trockenen, Duisburg. Available from https://www.binnenschiff.de/pressemitteilung/duerre-in-deutschlanderfordert-das-handeln-von-politik-und-verwaltung-binnenschifffahrt-auf-demtrockenen/.

Burnewicz, J. (2007a), Prognoza zapotrzebowana na usługi transportowe w Polsce do 2020 roku. In: Liberadzki, B., Mindur, L. (Eds.), Uwarunkowania rozwoju systemu transportowego 
Polski, Instytut Technologii Eksploatacji - Państwowy Instytut Badawczy, WarszawaRadom, p. 132.

Burnewicz, J. (2007b), Wizja struktury transportu oraz rozwoju sieci transportowych do roku 2033. Ze szczególnym uwzględnieniem docelowej struktury modelowej transportu, p. 41. Available from http://www.siskom.waw.pl/planistyka/polska/Burnewicz.pdf.

Dunaukommission (2017), Statistisches Jahrbuch der Donaukommission für das Jahr 2012, Budapest, Elektronische Bibliothek. Available from http://www.danubecommission. org/extranet/e-library/index.html.

Dunaukommission (2018a), Statistik der Donauschifffaht. Available from http://www.danubecommission.org/dc/de/die-donauschifffahrt/statistik-der-donauschifffahrt/.

Dunaukommission (2018b), Marktbeobachtung der Donauschifffahrt: Bilanz 2017, Budapest. Available from http://www.danubecommission.org/dc/de/die-donauschifffahrt/ marktbeobachtung-der-donauschifffahrt-bilanz-2017/.

European Commission (2019), Statistical pocketbook 2018. Available from https://ec.europa. eu/transport/facts-fundings/statistics/pocketbook-2018_en.

Eurostat (2019), Database. Available from https://ec.europa.eu/eurostat/data/database.

Główny Urząd Statystyczny (2018a), Transport wodny śródlądowy w Polsce w 2017 roku, Warszawa. Available from http://stat.gov.pl/obszary-tematyczne/transport-i-lacznosc/ transport/transport-wodny-srodladowy-w-polsce-w-2017-roku,4,8.html.

Główny Urząd Statystyczny (2018b), Transport wyniki działalności. Archiwum, Warszawa. Available from https://stat.gov.pl/obszary-tematyczne/transport-i-lacznosc/.

Główny Urząd Statystyczny (2018c), Transport wyniki działalności w 2017 roku, Warszawa. Available from http://stat.gov.pl/obszary-tematyczne/transport-i-lacznosc/transport/ transport-wyniki-dzialalnosci-w-2017-roku,9,17.html

Pieron, Ł. (2017), Inwentaryzacja części składowych śródlądowych dróg wodnych o szczególnym znaczeniu transportowym, Wydział Strategii Rozwoju, Departament Żeglugi Śródlądowej, Warszawa, pp. 10-13.

Wojewódzka-Król, K., Rolbiecki, R. (2017), Społeczno-ekonomiczne skutki zagospodarowania dolnej Wisty, Acta Energetica, Gdańsk, pp. 14-15.

Wznowiono transport wegla Odrą. Węgiel poptynąt z Gliwic do Wroctawia (2017). Available from http://next.gazeta.pl/next/7,151003,22097132,wznowiono-transport-wegla-odra-w egiel-poplynal-z-gliwic-do.html.

Załoga, E. (2013), Trendy w transporcie lądowym Unii Europejskiej, Wydawnictwo Uniwersytetu Szczecińskiego, Szczecin, p. 85.

Zentralkommission für die Rheinschifffahrt (2016), Jahresbericht 2016 Europäische Binnenschifffahrt Marktbeobachtung, Strasbourg. Available from https://www.ccr-zkr.org/files/ documents/om/om16_II_de.pdf.

Zentralkommission für die Rheinschifffahrt (2017), Jahresbericht 2017 Europäische Binnenschifffahrt Marktbeobachtung, Strasbourg. Available from http://www.ccr-zkr.org/files/ documents/om/om17 II de.pdf.

Zentralkommission für die Rheinschifffahrt (2018), Jahresbericht 2018 Europäische Binnenschifffahrt Marktbeobachtung, Strasbourg. Available from https://www.ccr-zkr.org/files/ documents/om/om18_II_de.pdf.

\section{Corresponding author}

Ryszard Rolbiecki can be contacted at: ryszard.rolbiecki@ug.edu.pl 